UDK 78.072 Lajovic

Simona Moličnik Šivic Ljubljana

\section{ANTON LAJOVIC V VLOGI STALNEGA KRITIKA NOVIH AKORDOV $^{1}$}

"Čemu se bojimo kritike, ki ji vendar ne uidemo? Zadela nas bo gotovo, če danes ne, morda jutri; če letos ne, morda prihodnje leto gotovo [...] Kdor Slovencem dobro hoče, naj z mano reče: "Bog živi kritiko!"

Fran Levstik, Napake slovenskega pisanja, 1858

Gornje Levstikovo mnenje se zdi, kakor da bi bilo pisano na kožo mlademu, energije in idej polnemu skladatelju in kritiku Antonu Lajovcu. Ob prelomu iz 19. v 20. stol. se je povsem jasno zavzel za to, da bi morali tudi na Slovenskem kritično in pošteno pisati o glasbi. Že na začetku lastne umetniške poti je uvidel šibkosti nerazvite glasbene kritike in poročanja o glasbenih dogodkih. Slovensko čitalniško izročilo se je proti koncu 19. stol. v resnici nadgrajevalo s temeljnimi vprašanji o glasbeni umetnosti, o nuji poklicne usposobljenosti ustvarjalcev, poustavrjalcev in glasbenih pedagogov. Spremembe $v$ celotnem razvoju domače glasbene kulture so bile tolikšne, da so samodejno terjale kritični pogled na doseženo ter tiste samobitne kali, iz katerih bi bilo potrebno zastaviti sistematični glasbeni program. Med tistimi, ki so se čutili najbolj odgovorne za glasbo v sodobnosti in prihodnosti na Slovenskem, je bil Anton Lajovic. ${ }^{2}$ $S$ svojim delom velja $v$ današnji glasbeno-zgodovinski zavesti kot nekdo, ki je "premaknil glasbena obzorja in slovenskemu skladatelju nakazal, kam naj ga pelje njegova ustvarjalna pot." ${ }^{3}$

Četudi je Lajovčev prispevek v glasbeno dediščino z začetka 20. stol. Razmeroma dobro osvetljen, ponujajo vzreli iz njegovega celokupnega publicističnega opusa gradivo, ki doslej še ni bilo podrobneje obravnavano, odtehta pa precejšnji delež v celotni podobi Lajovčeve osebnosti $z$ umetniške, idejne in nazorske strani. Komponirati in pisati o glasbi, dvoje povsem različnih oblik glasbenega dela, sta bili pri Lajovcu

1 Prispevek je le nekoliko preoblikovan izsek iz diplomske naloge, ki je obravnavala publicistično in kritično delo Antona Lajovca od začetkov (1907) do prve svetovne vojne. Ob tem dolgujem veliko zahvalo mentorici prof. Dr. Katarini Bedina, ki je vztrajno in neumorno bdela ob nastajanju naloge in mi $z$ dragocenimi strokovnimi napotki pomagala do oblikovanja končne verzije.

$2 \mathrm{Ob}$ njem še: Risto Savin, Benjamin in Josip Ipavec, Emil Adamič, Janko Ravnik in Gojmir Krek. To so skladatelji, ki so vsak s svojim trudom in po svojih močeh skušali obogatiti slovensko glasbo. Zgrnili so se $v$ krog strokovne revije Novi Akordi, ki je sprva (s strogo urednikovo sistematičnostjo) objavljala njihove, za tisti čas relativno moderne skladbe, kasneje pa je revija s prispevki $v$ literarni prilogi skušala dajati spodbude in smernice nadaljnemu razvoju. Prim.: Cvetko, D.: Slovenska glasba $v$ evropskem prostoru, str. 354-374.

3 Gl.: Cvetko, D.: Glasbeni svet Antona Lajovica, 137. 
docela uravnoteženi: zdita se kot enako pomembni vzporednici, $s$ katerima je bistril način govora $v$ partiturah in na soroden način brusil publicistične prispevke. $Z$ njimi je začel nastopati v javnosti kmalu, ko je zaključil "študentovsko brezdomstvo" ${ }^{4}$ in se ustalil v Ljubljani. Na Dunaju je izpopolnil znanje, pestro glasbeno življenje tega mesta pa mu je ob tem bistveno razširilo poznavanje glasbe drugih narodov. $V$ tem času je dobil tudi dober vpogled $v$ smisel in namen tuje glasbene publicistike in glasbene kritike. Počasi in sistematično je začel oblikovati idejo, da je treba na slovenskem spremeniti domačijsko (pristransko in največkrat diletantsko) pisanje o glasbi. V pošteni glasbeni kritiki, razčiščenih nazorih in idejah o glasbi je videl predpogoj, s katerim bi se utegnilo dvigniti slovensko glasbeno delo (vzgoja poklicnih glasbenikov in občinstva na višjo raven). Čutil se je sposobnega, da zmore s svojo osebnostno držo in vedenjem o glasbi vtisniti drugačne smernice $v$ glasbeno dogajanje na domačih tleh.

Pred prvo svetovno vojno je pisal kritike predvsem o koncertnih, opernih, zborovskih prireditvah ter kritike o novih glasbenih natisih, $v$ dvajsetih in tridesetih letih pa je pozornost obrnil $v$ splošne glasbene probleme, s katerimi se je srečevala tedanja slovenska glasba.

Obdobje od začetkov (1907) do prve svetovne vojne šteje kot zaključena faza v življenju tega izrednega ustvarjalca in misleca $v$ glasbi, zaznamovana $z$ izrednim elanom in trudom za "našo domačo reč", kakor se je sam rad izrazil. Pisal je za različne publikacije: politične dnevnike in literarne revije, $z$ rojstvom literarne priloge Novih Akordov leta 1910, pa se je Lajovcu šele odprla prava priložnost za strokovno poročanje o glasbi in vrednotenje prireditev, posameznih del ter vsega drugega, kar sodi v območje glasbene kritike. Kot stalni kritik Novih Akordov je med leti 1910-1912 (od devetega do enajstega letnika) priobčil 14 prispevkov v stalni rubriki Koncerti, ${ }^{5}$ eno $\checkmark$ rubriki Gledališče, ${ }^{6}$ eno obširnejšo objavo na prvi strani literarne priloge ${ }^{7}$ in dve opazki za Pêle-Mêle. ${ }^{8}$ Zaradi polemike, o kateri bomo pozneje govorili, je leta 1912 prenehal sodelovati z Novimi Akordi.

"Pod lupo" je postavljal predvsem tiste koncertne dogodke, ki so ga zanimali s kritičnega stališča o splošni glasbeni kulturi na Slovenskem in njenih nadaljnih perspektivah. Nekatere članke je napisal na izrecno urednikovo željo. Rokopisna zbirka NUK namreč hrani dopise uredništva Novih Akordov, ${ }^{9}$ nekatere od njih je urednik Gojmir Krek naslovil na Lajovica s prošnjo za kritično poročilo določenega koncerta.

Lajovčeve sodbe $v$ Novih Akordih so bile raznovrstne in strokovno prišpičene, saj so bile pisane za poklicne glasbenike in so se dotikale vseh oblik slovenskega glasbenega življenja. Ustvarjanje in poustvarjanje, vzgoja naraščaja in problem glasbeno estetskega umevanja so bili nekakšno jedro, okrog katerega je Lajovic

4 Po maturi (leta 1897) je Lajovic dobil štipendijo škofa M. Ravnikarja in za tem še Vossovo šripendijo za študij prava na Dunaju, ne pa na konservatoriju, kot si je sam želel. Ker želja po glasbenem znanju ni usahnila, se je obenem ( $v$ istem mestu) vpisal še na glasbeno akademijo. Študiral je kompozicijo pri Robertu Fuchsu. Zdi se, da je glasbenemu izobraževanju posvetil največ časa, zato je $z$ diplomsko nalogo - skladbo Gozdna samota za ženski zbor in orkester - že leta 1902 zaključil študij kompozicije, medtem ko je obveznosti na pravni fakulteti (s časovnimi presledki) nadaljeval v Gradcu in diplomiral leta 1907. Prim.: Cvetko, D.: Glasbeni svet Antona Lajovca, str. 10.

5 Gl.: Novi Akordi 9/1910, 1,2; 9/1910, 5, 31-32; 10/1911, 4-5, 52-53; 11/1912, 1, 4-5; 11/1912, 1,5; $11 / 1912,1,6 ; 11 / 1912,3,20 ; 11 / 1912,3,21 ; 11 / 1912$, 3, 24-25; 11/1912, 4, 41-43; 11/1912, 6, 47-48.

6 Gl.: NA 11/1912, 3, 25-25.

7 Gl.: NA 9/1910, 2, 9-10.

8 Gl.: NA 10/1911, 4-5, 61; 11/1912, 3, 32.

9 Gl.: Ms $94 / 47$ in $4 / 49$. 
razvijal in utemeljeval svojo idejo o glasbeni umetnosti na Slovenskem. Pozoren je bil na vse tiste koncerte in dogodke, ki so se mu zdeli pomembni za glasbeni razvoj na domačih tleh; bodi $v$ programskem in izvajalskem pogledu, bodi $v$ vodenju glasbene politike. Posebno skrbno je analiziral koncerte, ki so imeli na sporedih slovenske skladbe ali novitete in instrumentalne oziroma komorne koncerte, ki so se mu zdeli poustarjalno zanimivi - $v$ dobrem ali $v$ slabem. Nikoli pa ni pisal o javnih produkcijah učencev Matičine glasbene šole. Zdi se, da je te koncerte štel za samoumevno obliko pedagoškega dela. Objavljene kritike potemtakem zadevajo presojo novih skladb slovenskih skladateljev, njihove izvedbe, koncertnega življenja v splošnem, nemalokrat pa se dotikajo tudi glasbenega odziva pri poslušalstvu. Pod rubriko Koncerti so bile objavljene Lajovičeve kritike o dveh komornih koncertih ${ }^{10}$ in simfoničnem koncertu Slovenske filharmonije ${ }^{11}$ ter štiri o Matičinih koncertih. Na prvem Matičinem koncertu so izvajali iz slovenske glasbene literature Sattnerjevo Jeftejevo prisego, dva Adamičeva zbora, Kimovčev zbor Izgubljeni cvet, Schwabovo Dobro jutro in Jenkovo Vabilo; ${ }^{12}$ na drugem je bil prvič izveden Povodni mož Viktorja Parme. ${ }^{13}$ Tretji koncert je bil zanimiv zaradi prvič izvedenih sodobnih zborovskih skladb: Kreka, Michla, Adamiča, Premrla, Gerbiča in Deva, ${ }^{14}$ na četrtem koncertu pa je bila slavnostna premiera Sattnerjevega oratorija Vnebobzetja Marije Device. ${ }^{15}$ Kadar se ni nič dogajalo, je imel Lajovic še najbolj obrušen jezik. "Suha" sezona brez koncerta pevskega zbora Glasbene matice je rodila pikro kritiko, v kateri se je Lajovic spustil v presojo sosednjega slovenskega ansambla. Vmes je priobčil dve krajši recenziji o gostujočih koncertih, ki ju je priredila Glasbena matica ${ }^{16}$ in o zborovskem koncertu ljubljanske

10 Prvi komorni koncert je bil dne 1. Dec. 1909. Izvajalci so bili:pianistka Vida Prelesnik, solist Julijo Markucci in godalni kvartet $v$ sestavi Jan Rezek, Karel Kuček, Vaclav Talich in Edvard Bilek. Spored navaja skladbe ruskih skladateljev.

Drugi komorni koncert pa je bil 1. Aprila 1910. Igral je godalni kvartet $v$ isti sestavi kot na predhodnem koncertu. Programski list ni ohranjen, vendar spored navaja kritika v Slovenskem narodu. Igrali so P.I. Čajkovski, Beethovna ter Mendelssohna. Prim.: Koncertni sporedi Glasbene matice 1884-1914; Slovenski narod, dne 3.4.1910.

11 Koncert Slovenske filharomije je bil dne 31. Marca 1912. Ob orkestru so solistično nastopili: Pavel Kozina, Anny in Jan Kramper ter Hanny Haumer. Izvajali so. Schubertovo Simfonijo v C-duru, Dvorakovo uverturo Karneval, dva samospeva Wilhelma Kienzla in enega Gustava Mahlerja ter duet Ivana Zajca iz opere Nikola Šubić Zrinjski. Prim.: Slovenski narod, dne 2.4.1912.

12 Koncert Glasbene matice je bil 9. Marca 1910. Izvajalci so bili: pevski zbor GM, orkester SF, basist Julij Betetto, baritonist Ivan Levar (takrat še študent) in pianistka Vida Prelesnik.

Spored ima pripisano opombo: "Pevski zbor izvaja izključno najnovejše slovenske izvirne, še nikjr izvajane koncertne točke." Prim.: Koncertni sporedi Glasbene Matice 1884-1914.

13 Koncert je bil dne 10. Maja 1911. Nastopili so: pevski zbor GM M. Hubadom, orkester SF pod vodstvom E. Czajaneka, sopranistka Pavla Bole s pianistom Jankom Ravnikom ter tenorist Leopold Kovač z Antonom Trostom. Prim.: Koncertni sporedi Glasbene matice 1884-1915.

14 Koncert je bil 14. Feb. 1912; uvedel in sklenil ga je orkester Slovenske Filharmonije z Vaclavom Talichom, srednji del sporeda je izvajal zbor Glasbene marice z Matejem Hubadom in solistko Pavlo Lovšetovo (sopran). Na koncertnem listu je dodana opomba, da bosta Lajovčevi skladbi izvajani tretjič, Parmova pa drugič, medtem ko bodo vse ostale prvič izvedene. Prim.: Koncertni sporedi Glasbene marice 1884-1914.

15 Krstna izvedba oratorija je bila precej pompozna, nastopilo je okrog 300 ljudi. (Podobno kot pri Verdijevem Requiemu, le da je bil ta koncert pomembnejši, saj je šlo za domače delo). V obsežni koncertni brošuri je bilo objavljeno besedilo M. Opeke in podrobnejša analiza, ki jo je napisal Stanko Premrl. Solisti so bili: Pavla Lovše (sopran), Jeannetta Foedransperg (sopran), Ljubiša llič (tenor) in Josip Križaj (basbariton). Prim.: Koncertni sporedi Glasbene Matice 1884-1914.

$16 \mathrm{Na}$ prvem, dne 15. Okt. 1911 je nastopil češki tenorist Karl Burian (sicer pevec Dunajske dvorne opere) skupaj $z$ orkestrom Slovenske filharomije pod Talichovim vodstvom. Programje bil bojda povsem drugačen kot je bilo zapisano v napovedi. Časopisi navajajo, da je orkester igral Mendelssohnovo uverturo Hebridi in Lajovčev Andante, tenorist pa naj bi zapel arije iz Webrovega Čarostrelca, Smetanovega Daliborja, Wagnerjevega Tanhauserja ter samospeva za tenor in orkester Wilhelma Kienzla 
Pevske Župe. ${ }^{17}$ Zadnje kritično poročilo pod rubriko Koncerti se nanaša na nastop pevskega društva Ljubljanski zvon. ${ }^{18}$ Obsežnejša recenzija novega natisa Savinove opere Lepa Vida ni bila objavljena pod nobeno od rubrik, temveč kot osrednji prispevek v reviji. ${ }^{19}$ Pod rubriko Gledališče je izšel le en Lajovčev prispevek v 3. številki 11. letnika (1912), v katerem je izčrpno poročal o dejavnosti slovenske opere v prvi polovici sezone 1911/1912. ${ }^{20}$ Napisal je tudi dve opazki za rubriko Pêle-Mêle. ${ }^{21} \mathrm{~V}$ prvi se je obregnil zoper nestrokovno početje nekaterih glasbenih piscev, $v$ drugi pa se je razjezil zaradi nedoslednega reklamnega oglašanja. Svoje "principielno stališče", kakor se je izrazil, o delu glasbenega kritika, da je bil razložil $v$ enem začetnih prispevkov. ${ }^{22} \mathrm{Tu}$ je nadalje razvijal svoje misli o tem nelahkem delu glasbenega kritika, ki ga je načel že leta 1905 v Novi dobi. ${ }^{23}$ Pojasnil je, da ločuje dva načina pisanja glasbene kritike: tiste za širši krog bralcev, ki navadno izhajajo $v$ dnevnem časopisju, in za glasbenike, ki jih večinoma najdemo $v$ strokovnih glasilih. Pravi način pisanja glasbene kritike naj bi po njegovem vzgajal občinstvo, naj "se navadi pri umetninah najti njihove pozitivne strani, njihove vrline in njihovo lepoto." ${ }^{24}$ Te vrste kritika naj bi bila po Lajovcu skoraj propagandno spodbudna, kajti po njegovem "občinstva, kateremu je poročilo $v$ dnevniku namenjeno, prav nič ne brigajo slabosti in napake umetnin. Zakaj poznanje teh slabosti in napak je za publiko brez vsake koristi." $\mathrm{S}$ tem je mislil na povprečno (ali podpovrečno) glasbeno izobrazbo ljubljanskih poslušalcev, ki so težje razumeli sodobno glasbo. Zato je zahteval takšno kritiko, ki naj bi dopolnjevala njihovo vedenje o glasbi in jim pomagala do estetskega umevanja. Najprimernejše naj bi bilo neposredno izobraževanje ob posameznem glasbenem delu, češ da je "vzgoja ob umetninah [...] vzgoja k občutevanju lepote." O sodobnih slovenskih kritikih je menil, da so rajši opozarjali na šibke točke izvedbe, namesto da bi bili orisali značaj umetniškega dela. Zato naj bi poslušalci sledili le kakovosti izvedbe, ne pa teži glasbene umetnine. Njihovo obnašanje je Lajovic takole orisal: "Pride tak človek (ki

in Gustava Mahlerja, Mesec dni za tem, 12. Nov. 1911, je igral znameniti Ševčikov kvartet iz Prage v sestavi: B. Lhotsky, K. Prochazka, K. Moravec in L. Zelenka. (Otokar Ševčik je bil profesor na Dunajski glasbeni akademiji in vodja violinske mojstrske šole te ustanove).

Izvajali so: Dvorakov Godalni kvartet v G-duru, op. 106, Glazunov v a-molu, op. 64 in Beethovnov v F-duru, op. 135. Prim.: NA 11/1912, 1, 14; Slovenski narod, dne 10. Okt. 1910; Koncertni sporedi Glasbene matice 1884-1914.

17 Ljubljanska Pevska Župa je 13. Aprila 1912 piredila koncert, na katerem sta sodelovali pevski društvi Ljubljanski zvon in Slavec ter orkester Slovenske filharmonije, prvič z novim dirigentom Petrom Teplyjem. Zborovski spored je zaokrožil orkester Slovenske filharmonije. Na začetku so zaigrali Webrovo uverturo Oberon, z sklep pa Dvorakov Slovanski ples ter drugo Lisztovo Madžarsko rapsodijo. Prim.: NA 11/1912, 5-6, 47; Slovenski narod, dne 12. Aprila 1912.

18 Glasbeno društvo Ljubljanski zvon je 15. Okt. 1911 priredilo tako imenovani Ipavčev večer. Na koncertu so sodelovali: Jeanetta Foedransperg (sopran), Ljubiša llić (tenor), in moški zbor pevskega društva Ljubljanski zvon. Prim.: NA 11/1912, 5-6, 47; Slovenski narod, dne 16. Okt. 1911.

19 Opero v štirih dejanjih je skladatelj končal leta 1907, prvič pa je bila izvedena 18. Dec. 1909 v Deželnem gledališču v Ljubljani. Prim.: Rijavec, A.: Slovenska glasbena dela, str. 259.

20 Prva polovica sezone 1911/1912 je bila precej bogata. Med predstavami so sicer prevladovale operete, premierno pa so uprizorili tudi tri opere. $\mathrm{V}$ prvi polovici sezone so sezvrstile naslednje uprizoritve: Grof Luksemburški (12. Dec. 1911), opereta v treh dejanjih Franza Leharja, Bizejeva Carmen (22. Dec. 1911), Revizor (23. Jan. 1912), opereta v 3 dejanjih Karla Weisa, Dvoraka Rusalka (8. Febr. 1912). Caričine Amazonke (13. Feb. 1912), opereta $v 3$ dejanjih Viktorja Parme, nato opereta $v$ treh dejanjih Františka Neumanna z naslovom Ljubimkanje (7. Marec 1912). Prim.: Repertoar Slovenskih gledališč, str. 202.

21 Prvo v 4-5 številki 10. Letnika (1911) in drugo v 3. Stevilki 11. Letnika (1912).

22 Gl.: NA 9/1910, 4-5, 31.

23 Gl:: Nova doba $1 / 1907,1,1$.

24 Lajovic je rad poudarjal besedilo (s podčrtavanjem, poševnim ali mastnim tiskom). $V$ citatih jih navajam dosledno tako, kot je zapisano na viru. 
bere kritike) $v$ razstavo, $v$ koncert in čaka, kakor pajk muhe, edinole, kje bi kako napako zaskočil, kje je kaka roka ali noga zarisana, kje se pevcu ali instrumentalistu kak ton ponesreči [...]. Čim več napak najdenih, tem večja naslada in zmagoslavje, kakor bi se glasbena izobrazba merila po izurjenosti $v$ iskanju napak." Meril je na tiste pisce, ki so poslušalčevo pozornost obračali v zunanjost dogodka, namesto da bi jih pripravljali na vsebinsko doživetje glasbene umetnine. Zato je kar revolucionarno zahteval "korenit preobrat $v$ načinu vseh onih kritik, ki so namenjene širšemu občinstvu. [...] To se mora izpremeniti!", je velel in nato po svoje opisal kritično izračanje: "Kritika [naj] bi [...] ne žvenkljala $s$ praznimi besedami in ne žonglirala $z$ brezvsebinskimi izrazi, marveč $z$ resnično novo vsebino bogatila [zaznavanje]." ${ }^{25}$

Drugačna merila pa je postavljal kritiki v strokovnih revijah, kakršni so bili Novi Akordi. Tudi ta naj bi vzgajala, vendar drugi krog poslušalstva. Neposredno naj bi dopolnjevala praktično znanje glasbenikov vseh vrst. Opozarjala naj bi na napake in popisala morebitne boljše rešitve ob "konkretnem" zgledu. Lajovic je v obliki nekakšnega kreda označil svoje kritiško načelo: "Nedostatkov in napak torej ne podčrtavam, da bi se očitale onemu, $v$ čigar delih so, marveč vsaka izmed njih bodi stopnica $k$ novemu višjemu napredku." ${ }^{26}$

Dveh vrst glasbene kritike se je dosledno držal tudi sam. Zgled za to najdemo v kritiki istega koncerta (Glasbene matice, dne 9. marca 1910) v Slovenskem narodu: ${ }^{27}$ $v$ Novih Akordih je strokovnjak, v Slovenskem narodu pa kritik za širše bralstvo. V dnevniku Slovenski narod je naštel vse izvajane skladbe, jih orisal po značaju ter pohvalil "umetelnost" njihovih ustvarjalcev in izvajalcev. V Novih Akordih pa je koncentriral pisanje na nove slovenske skladbe, jih skrbno analiziral ter precej strožje presodil umetniško kakovost kakor pričujočo izvedbo. Takšni so bili vsi naslednji prispevki v Novih Akordih (1910-1912), pisanje za dnevno časopisje pa je v tem času opustil.

Lajovic se je zavedal, da mora obstajati skoraj intimno razmerje $v$ koncertni dvorani med poslušalci, izvajalci in umetnino (umetnikom). Veriga se mu je zdela pretrgana zlasti pri izvedbah novejših del, na katere se je občinstvo slabo odzivalo. Sociološki vidik, ki je zaviral slovenski glasbeni razvoj, je Lajovic pravočasno opazil in nanj prvič reagiral že v eseju, objavljenem v Novi dobi (leta 1905). ${ }^{28}$ Zaznal ga je ob praznih dvoranah, zlasti kadar je šlo za koncertni dogodek. Sprva se je slabšega obiska te vrste koncertov sicer razveselil, saj je menil, da se je občinstvo "izkristaliziralo", in da so redki poslušalci prišli resnično zaradi notranjega vzgiba in ne zavoljo družabne prisotnosti. Vendar ni spregledal, da je postajal obisk vedno skromnejši, avtonomna instrumentalna glasba pa brez ustrezne podpore občinstva. $\mathrm{Ob}$ poslovilnem koncertu Václava Tálicha je zapisal, da mu občinstvo dolguje zahvalo "za toliko lepih vžitkov" ${ }^{129}$ ne pa tolikšne nezdrave in hladne brezbrižnosti. V eni zadnjih kritik se je obrnil na občinstvo, češ, da neposluša glasbe, temveč je zmožno sprejemati le zunanje (vidne) okoliščine. Vzrok za to je videl v nestrokovnih kritikah dnevnega časopisja: "Naša publika je že itak po naturi obdarjena s sijajno kratkovidnostjo glede

25 Gl.: NA 9/1910, 4-5, 31.

26 Gl.: NA 9/1910, 4-5, 31.

27 Gl.: Slovenski narod 43/1910, (10.3.), št. 56, str. 3.

28 Gl.: Nova doba $1 / 1907,1,1$.

29 Gl.: NA 11/1912, 3, 21. 
estetičnih lepot; ali dosedanja dnevna kritika, vedno le na slabosti opozarjajoča, je publiko $v$ tem pogledu udarila naravnost $\mathrm{s}$ slepoto". ${ }^{30}$

Lajovcu je bila najpomembnejša estetska vrednost umetnine. Vemo, da je od ustvarjalcev in izvajalcev zahteval pretanjeni estetski čut. Cenil je pristno, spontano dogajanje $v$ kompozicijskem procesu, zavračal pa vsakršen prisiljen nelogičen (protinaraven) postopek. Vzor "lepote" je najrajši poiskal v glasbi Antonína Dvořaka, kjer se vse izteka "tako naravno, tako nevažno in samo po sebi umevno, tako prešinjeno z žarom globokega muzikalnega občutja in zanosa, da stojiš pred njegovim delom kakor pred čudežno stvaritvijo narave božje". ${ }^{31}$

Dvorakovo glasbo je doživljal kot "resnično, naravno močno čustvo.." ${ }^{32}$ Med novimi slovenskimi deli je $v$ tem smislu pohvalil le skladbe Benjamina Ipavca, ki so "po svoji melodični mehkobi in intimnem občutju [...] kakor ustvarjene za to, da bi postale popularne v najlepšem pomenu besede", ${ }^{33}$ ter Viktorja Parmo, češ da ima "smisel za umetniško ubranost". ${ }^{34}$ Kakor hitro se je srečal $z$ neokusnim in izumetničenim delom, je njegovo pero postalo ostro in zbadljivo: Opereto Ksenija istega skladatelja je označil kot "predhodno delo", kjer se glasbeni izraz ne sklada z besedno vsebino: "Vsa Ksenija se navzlic svojim deloma krvavim zapetljajem [mislil je na vsebino libreta] preliva $v$ muzikalnem oziru iz ene sladkosti v drugo. Naj se [na odru] godi karkoli, Parma nataka skoro same sladke melodije, pita publiko s samim sirupom. ${ }^{.35}$ Neokusna se mu je zdela tudi Kimovčeva harmonizacija Izgubljenega cveta. Očita ji preprosto zamisel, ki jo "kar naenkrat" začne s "kromatičnim spakovanjem!" $V$ takšnih primerih je postal žaljiv s prispodobami, ki sicer niso sodile $v$ njegov besednjak: "Za takole mesto bi Kimovca, če bi ga imel blizu, z razbeljenimi kleščami vščipnil in prav nič usmiljenja bi ne čutil zraven!" ${ }^{136}$ Skladatelj bi moral namreč s svojim talentom ustvariti estetski čut glasbenega izraza. Glasbene prvine naj bodo tako izpeljane, da bosta skladateljeva misel in čustvo harmonično "prevedeni" v tonski jezik.

Zanimivo, da je za zgled glasbenega izražanja imenoval Beethovna, ki ga v resnici ni maral postavljati za zgled. Menil je, da nam je Beethoven sicer tuj, vendar, "koder Beethovnov elementarni humor bruhne na dan, tam človeka še vedno zgrabi sila in krepčina Beethovnovega izraza." ${ }^{37}$ Prepričljiv glasbeni izraz "nežnega, intimnega, gracijoznega občutja," je opazil v drugem dejanju Savinove Lepe Vide, ${ }^{38}$ nasprotje tega pa $v$ "ognjeviti" glasbi P. I. Čajkovskega, "ki je zakurila igralcem in podžgala tudi publiko." ${ }^{39}$ Dolgočasnega ponavljanja melodičnih, ritmičnih ali instrumentalnih obrazcev, prav tako ni maral. V Savinovem sklepnem dejanju Lepe Vide je takole opozoril: "V [...] stoični metež zbora se $v$ kratkih presledkih oglašajo spodbudne trombe glasi. Vztrajno kot neumorni misijonarji ali brez upa zmage. In človek je nazadnje žalosten zborove veselosti in sit spodbujajočih klicev združenih trobil. Zakaj ti in oni [misli na trobila in zbor] oboje je jednako leseno. Te klice, vrag jih vzemi! Čim večkrat

30 Gl.: NA 11/1912, 3, 25.

31 GI.: NA 11/1912, 1-2, 5.

32 Gl.: NA 11/1912, 3, 23.

33 Gl.: NA 11/1912, 1-2, 6.

34 Gl.: NA 10/1911, 4-5, 53.

35 Gl.: NA 11/1912, 3, 22.

36 Gl.: NA 9/1910, 4-5, 32.

37 Gl.: Mislil je na Beethovnov septet, ki je bil izveden na komornem koncertu, dne 1. aprila 1910. Gl.: NA 9/1910, 4-5, 33

38 Gl.: Risto Savin: "Lepa Vida", NA 9/1910, 2,10.

39 Gl.: NA 9/1910, 4-5, 32. 
sem jih slišal, tem bolj sem klel njihovo dolgočasnost." ${ }^{40}$ Po njegovo mora biti glasbeno delo vseskozi zanimivo, kontrastno in nerazvlečeno, tako da poslušalci ne bi mogli svojih misli obračati drugam; zato morajo skladateljeve odločitve učinkovati premišljeno in izborno. Zunajglasbene prvine (besedilo ali scena pri opernih delih) so bile za Lajovca le stranskega pomena, ki bi nikakor ne smele zamegliti glasbenega poteka. Tudi na to je opozoril ob sklepu Savinove opere. Podvomil je v prvenstveno vlogo glasbe, omenjeno recenzijo je kar nestrpno zaključil: "Tu [na koncu opere] je toliko zanimivosti na kupu, da do danes ne vem, kakšna je glasba $v$ teh scenah in ali je je sploh kaj, vsled česar je nujno mojega glasbenega sporočila konec." $V$ drugem dejanju opere je Savin ponazarjal italijansko dramatično barvitost. Lajovic mu je očital pretirani "laški" vpliv in hitre dramatske razplete, ki po navadi ne zgrešijo zunanjega efekta. (Alberto je ob koncu zadavljen, Vidin mož zaboden, nato pa še Vida znori). ${ }^{41}$

Tembolj "prefinjeno" izražena dramatika se mu je zdela v Dvořakovi Rusalki. "Res [,] da je zunanje dogajanje $v$ "Rusalki" zelo preprosto in da nima zunanjih dramatičnih senzacij, toda kako bogastvo duševnega dogajanja pričara $v$ to preprosto snov skrivnostna moč Dvořakove glasbe, katera kot $s$ tajinstvenimi žarki osvetli in prikaže najgloblje in najskrivnejše čustvovanje $v$ drami prizadetih oseb, čustvovanje, ki ga beseda ne izda in prikrita kretnja ne pove, temveč katero komaj čutno zatrepeče $v$ tonu govora. [...] Edino glasba je [...] v trenutku kot odgrnila zaveso in pokazala žaloigro, dotlej ne izrečeno, ne predstavljeno, komaj z gesto nakazano, vso le globoko v Rusalkini duši vršivšo se žaloigro Rusalkine ljubavi.." ${ }^{42}$ Rusalkino tragedijo je dojel "v jeziku glasbe, $v$ tonih" ${ }^{43}$ Lajovic je bil v začetku 20. stol. med redkimi slovenskimi skladatelji, ki je dramatičnost besedila zavestno in vseskozi kontrolirano gradil z izključno glasbenimi sredstvi (melodiko, harmonijo, ritmom in instrumentacijo). Motilo ga je vse, kar je odstopalo od tega načela. Pri presoji Parmovega Povodnega moža je tehtal vsebino besedila in njegov "prevod $v$ glasbeni jezik" ter se spraševal: "ali odgovarja glasbeni izraz in glasbena ubranost Prešernovi baladi, je li izražanje individelno in zanimivo. ${ }^{44}$ Očital mu je, da v izbiri glasbenih sredstev ni bil dovolj premišljen; preveč naj bi bilo poljubnega operetnega postopka, ki ni primerno za tehtnejše delo, kakršno je Prešernova balada. Po estetski in izrazni vrednosti je besedilo odtehtalo glasbo, zato naj bi v Povodnem možu precejšnje neskladje občutil med besednim in glasbenim dramatskim ustrojem. V zvezi s tem je zahteval od skladateljev veliko mero okusa tudi pri izbiranju literarnih predlog. Odkrito je povedal, da mu Adamičev moški zbor Scherzando na besedilo Rudolfa Maistra ni bil všeč. Čeprav se mu je zdela glasba "dobro občutena," ${ }^{45}$ jo je netehtno besedilo oškodovalo za umetniško vrednost, ki bi jo bila sicer zaslužila. Tudi Stanku Premrlu, skladatelju, ki se je večkrat $v$ javnosti zavzemal za premišljeno izbiro besedila, posebno $v$ erotičnih primerih, ni bilo prizanešeno. ${ }^{46} \mathrm{~V}$ eni od kritik je Lajovic povedal, da je bil "nesrečen"

40 Gl.: NA 9/1910, 2, 10.

41 Gl.: NA 9/1910, 2,10.

42 Gl.: NA 11/1912, 3, 25

43 Gl.: ibid.

44 Gl.: NA 10/1911, 4-5, 52

$45 \mathrm{Gl}:$ NA $9 / 1910,4-5,32$

46 Skladatelja in duhovnika Hugolin Sattner ter Stanko Premrl sta v 3. številki 10. letnika NA za Pêle-Mêle napisala prispevek z naslovom: Erotika in "Novi akordi". V njem sta opozorila skladatelje, da naj ne izbirajo erotičnih besedil in naj ne "opevajo" greha. Za zgled tako imenovanega erotičnega besedila sta navedla moški zbor Vasilija Mirka, Katrica in mešani zbor J. Pavčiča, Kaj ve misli?, oba objavljena v 1 . št. 10. letnika NA. Uredništvo je pod objavo napisalo svojo pripombo, češ, da je to besedilo mogoče 
zaradi "brezupnega teksta", ki si ga je bil Premrl izbral v Pesmi žerjavov. Ironično je izpisal sklepne verze, ki jih je označil za "že kar erotične" ${ }^{147}$ in kritiko metaforično zaključl: "Pa naj že bo erotično, kolikor če, saj meni to nič mar; ali ob enem je ta tekst tako toriccelovsko ${ }^{48}$ prazen, tako brezmejno pust in dolgočasen, da je strah; pravi pristni tipus poetarskega proizvoda." Vemo, da je bil Premrl cecilijanec in pristaš konservativne struje. Lajovcu seveda ni šlo za svetovni nazor, temveč za resnično umetniško stremljenje, ki obvezuje slehernega posameznika v umetniškem snovanju. Gornje opozorilo je Lajovic prijateljsko zaključil s stavkom v latinščini: "Hic Lenard est, hunc tu amice caveto! ${ }^{49}$ Leopold Lénard ${ }^{50}$ je bil namreč avtor besedila Pesmi žerjavov.

Bolj uglašeno razmerje med besedo in glasbo je Lajovic našel $v$ Jenkovi zborovski skladbi Vabilo. Štel jo je za "lepo ubrano" in priznal, da imamo "malo [...] stvari, ki bi imele $v$ sebi tako lepe kontraste in bi bile obenem tako lepo zaokrožene in tako enotne. ${ }^{51}$ Težnjo po enovitosti je opazil tudi $v$ prej obravnavanem Povodnem možu Viktorja Parme. Pripisal mu je "očitno stremljenje, da bi prišel do ubranega razmerja med besedo in zvokom. ${ }^{52}$ Večkrat pa je slovenske skladatelje opozarjal tudi na "razkosanost", "razcepljenost" in "racefranost", zlasti v večjih glasbenih oblikah. Pri Sattnerjevi kantati Jeftejeva prisega ga je motila "razdelitev dela v toliko malih stavkov", ki trga potek skladbe in "na zelo neprijeten način vedno iznova prekinja in jemlje delu ravno ono, kar mu je vsled izbrane snovi bistveno, namreč nepretrgan, z elementarno silo za seboj potegujoč[i] tok [...]. ${ }^{153}$ Brezhibno oblikovno znanje in sposobnost za obvladovanje manjših $v$ večje glasbene oblike sta se mu zdela kot osnovna pogoja za skladateljevo delo. Skladatelj mora znati (tudi takrat, ko nima podpore $v$ besedilu) izoblikovati formo; sam mora z zanesljivo roko "zgraditi muzikalno periodo in dalje graditi $z$ danim materijalom. ${ }^{154}$ Pri Sattnerjevem oratoriju Vnebovzetje Marije Device je opazil, da "nastopajo stavčki drug za drugim kakor v kakem potpourriju". ${ }^{55}$ Pri tem je podčrtal "življenjski" pomen kontrasta $v$ glasbi, posebno $v$ obsežnejših zasnovah.

Red in discipliniran kompozicijski postopek sta bila $v$ Lajovčevem publicističnem in kritičnem pisanju druga dva temeljna pogoja za kompozicijsko tvornost. Prepričljivo ju je izrazil prav v kritični presoji Sattnerjevega oratorija. Sicer je pohvalil skladatelja,

razumeti tudi drugače, kot "moralno svarilo" $z$ ironičnim poudarkom, da "Kitscha res ni treba poveličevati ali ovekovečiti $z$ glasbo." Zdi se, da je ta opomba zadevala ravno v Sattnerjeva in Premrlova (večkrat literarno manj vredna) besedila. Prim.: NA 10/1911, 3, 44.

47 Verzi se glase: "Mi gremo tja, kjer bujna kri po žilah se pretaka;

življenje neutešeno $z$ nemirno silo čaka.

Gl: NA 11/1912, 3, 20

48 Torriceli Evangelista (1608-1647) je bil italijanski fizik in matematik, ki je odkril živosrebrni barometer in prvi dosegel vakuum v zaprti cevi. Bil je sodelavec G. Galilea. Prim.: Leksikon Cankarjeve založbe, 3. izdaja, Ljubljana 1994, str. 1090.

49 "To je Lenard, pazi se ga ti prijatelj!" Gl.: NA 11/1912, 3, 21.

50 Leopold Leonard je bil publicist, rojen 1876 v Svibnemu. Študiral je teologijo $v$ Innsbrucku, filozofijo $v$ Lvovu in na Dunaju ter oba študija zaključil z doktoratom. V letih 1908-1914 je opravljal duhovniški poklic v Ljubljani, nato v Borovnici, Slapu pri Vipavi, Mariboru, po prvi svetovni vojni pa se je preselil v Beograd. Prim.: SBL, str. 634.

51 Gl.: NA 9/1910, 4-5, 31.

52 Gl.: NA 10)1911, 4-5, 53.

$53 \mathrm{Gl} .:$ NA 9/1910, 4-5, 31

54 Gl.: Oratorij "Vnebovzetje Marije Device" Hugolina Sattnerja; NA 11/1912, 4, 41.

55 Gl.: ibid. 
češ, da "pada [...] v oči njegova brezdvomna spretnost, kadar operira z vokalnim aparatom", nadaljeval pa je precej drugače: "kakor hitro pa začne delati samo z orkestrom, je nesiguren, postaja gostobeseden in blebetav: govori po vrsti znane reči, važne in nevažne, ki nimajo nobene zveze med seboj. ${ }^{156}$ Nediscipliniranost je opazil tudi pri Viktorju Parmi. S Povodnim možem kot celoto je bil zadovoljen, vendar mu očita premajhno "izbirčnost v izberi in porabi muzikalne misli," ker da je Parma kot skladatelj nasploh "preveč prijazen in domač z vsakim muzikalnim znancem, ki ga srečajo njegove misli.. ${ }^{57}$ Dal je vedeti, da je Parma sicer globoko nadarjen, vendar ne dovolj samosvoj in premišljen ustvarjalec.

Kadar je Lajovic ocenjeval glasbena dela, je najprej orisal delo kot celoto in nato analitično pronical do prvin, ki so se mu zdele odločilnega pomena za kritično ovrednotenje. Melodiko je postavljal na prvo mesto kot pogoj "glasbene lepote". V njej naj bi skladatelj izražal "občutje", ki naj se "razživi na široko", kajti "širina v glasbi" je "prepotrebna". Melodika je po Lajovcu obraz skladbe, bistvo umetniškega dela. Pojme, kot so "melodija", "občutenje", "širina", in "izraz" je Lajovic tesno povezoval med seboj. V kritikah jih je stalno pogrešal kot "neizpolnjeno upanje," ${ }^{\text {"58 }}$ ( $\mathrm{v}$ presoji Parmovega Povodnega moža). V Savinovi Lepi Vidi, delu, ki ga je sicer izredno cenil, se mu je zdelo, da "manjka prepotrebne širine", in da je "vsako občutje [...] mahoma pretrgano, prekratko, "kajti" slušalec, komaj uveden v eno občutje, je [...] iz prvega iztrgan, tako da niti nima časa, da bi svoj duševni pogled vstavil $v$ primerno razpoloženje. ${ }^{159} \mathrm{Po}$ njegovo mora biti v operi "vsaka gesta popočasnjena [in] široka". Zato naj se "vsako občutje razživi na široko", dogajanje pa naj bo "navezano na širokopotezen, priprost razvoj." "60 Glasbeno delo brez izrazite melodike se mu je zdelo "megleno, brezizrazno" ter "bolj konstruirano (kakor) občuteno". ${ }^{61} \mathrm{Ker}$ je zanj melodija nadrejena vsem ostalim glasbenim prvinam, bi morala biti, ne glede na lirični in dramatični značaj, jasna, čista in neobremenjena $z$ ritmom, harmonijo ali instrumentacijo. Ob Sattnerjevi kantati Jeftejeva prisega je zapisal, da je "[eno] mesto ${ }^{62}$ po svoji melodični liniji in v harmonični barvi izvrstno občuteno, ali orkester, žal, kar k tlom tišči s svojo masivnostjo." ${ }^{63}$ Kljub temu je opazil kompozicijsko napredovanje Hugolina Sattnerja. V naslednjem Sattnerjevem oratoriju (Vnebovzetje Marije Device), ki ga je poznal le v klavirskem izvlečku, je zaznal mesta, ki so ga spominjala na mojstrstvo Dvořakove Rusalke. Priznal jim je pristno "melodično gorkoto in sladkost". Sattnerjevo uglasbitev "prelepe" biblične pesmi: "Kot pečat me deni na svoje srce [...]" je imenoval z "rožo", močno in čustveno prekipevajočo. ${ }^{64}$ Tako na dolgo in široko se Lajovic ni razpisal o nikogaršnji melodični invenciji več.

Harmonija je bila v Lajovčevih kompozicijskih nazorih na drugem mestu, takoj za melodiko. Postavil se je $v$ bran "novim akordom", svežim akordičnim povezavam,

56 Gl.: ibid.

57 Gl.: NA 10/1911, 4-5, 53.

58 Gl.: NA 10/1911, 4-5, 52

$59 \mathrm{Gl} .:$ ibid.

60 Gl.: ibid.

61 Gl.: NA 9/1910, 4-5. 32

62 "Gre za zborovski del "A Jefte, glej, je smrtno bled."

63 Gl.: NA 9/1910, 4-5, 32.

64 Sattnerjevo uglasbitev je takole opisal: "In kot mehek bršljan se vije ob njej melodija, tako krotka in ob enem tako močna in iskrena, en sam vzdih, do ekstaze prekipevajoč in prepoln čustva. Popolnoma me je prevzela in cel dan me ne izpusti, potaplja me $v$ ginjenost. Blagovano srce, iz katerega je izrasla ta pesem roža!!" Gl.: NA 11/1912, 4, 41. 
"brezobzirnosti" in "predrznosti" v vertikali, kakršno je ustvarjal Risto Savin, čeprav se $\mathrm{mu}$ je zdel ta skladatelj pogosto "previhrav". ${ }^{65}$ Lajovic je bil pač dosleden v obrambi estetskega čuta, posebno kadar sta ga izdajala pomanjkljivo teoretično znanje in slabše razvit glasbeni okus. Pri analizi Parmove skladbe Povodni mož je resnicoljubno povedal, da se mu zdi moč njegovih modulacij in sploh moč harmonije - minimalna. Z zgledom je posvaril tudi druge slovenske skladatelje, da sta "tonika in dominanta" in njima najbližje sosede primerne le še za opereto, ne pa za skladbe "močnih in strastnih občutij", kakršna je Povodni mož. Obregnil se je seveda še ob vseh druge vrste kompozicijskega diletantizma ali konservativnosti. Zahteval je neprestan študij, še posebno študij modernih skladb, če se hočemo $v$ glasbi modernizirati: "Kajti $v$ umetnosti je modernizem, t.j. napredek in razvoj dogma, in kdor vozi po starih, izvoženih tirih in ponavlja stare, že od starih dovolj dobro in definitivno povedane reči, anathema sit!" ${ }^{66} \mathrm{~S}$ tem je meril tudi na načelo izvirnosti, ki je bilo zelo živo in $v$ duhu sodobnih prizadevanj zunaj slovenskih meja. Ritmu kot kompozicijskemu sredstvu Lajovic ni pripisoval važnega pomena. $V$ kritikah je opozoril le na morebitne napake. $V$ Schwabovem zboru Dobro jutro je začutil nepravilno izmenjavanje težkih in lahkih dob. Ritem je bil zanj "kruljev" in "nesiguren", kar je v poslušalcu spodbujalo notranji nemir. ${ }^{67}$ Pri tem opozorilu je izpisal notni zgled, točno označil napako in predlagal boljšo rešitev.

Za Lajovca je bila "lepa glasba" torej takrat, kadar je skladatelj dosegel s prvinami tonskega gradiva in kompozicijskimi sredstvi prepričljiv glasbeni izraz. Glasbo je umeval kot zrcalni obraz individualne umetnikove duše, ki $z$ dobro izvedbo prehaja $v$ tisočerih podobah na poslušalstvo. $V$ tem smislu je presojal umetniško vrednost glasbenega dela. "Lepo glasbo" je Lajovic "gorko občutil", v nasprotnem primeru pa je zapisal, da ga je "pustila mrzlega". Omenjena Kimovčeva zborovska skladba Izgubljeni svet ga "ni ganila", ker se mu je zdela preveč hladna "presukava" v melodiki, glasovi pa vodeni "trdo in grčavo". ${ }^{68}$ Moški zbor Gojmirja Kreka, Bratje, v kolo se vstopimo, ni "napravil nobenega vtiska" niti nanj, niti pri občinstvu, je zapisal; kajti skladba "ni iz srca svojih kali pognala," ${ }^{69}$ medtem ko je za njegovo zborovsko Barčico sodil, da "iz nje veje gorka čustvenost in lepa ubranost. ${ }^{70}$

Glasbo drugih slovanskih narodov je Lajovic cenil in jo zelo rad presojal. Godalni kvartet v D-duru Aleksandra Borodina je pohvalil zaradi "sloke oblike, nasičene vsebine in lirične nežnosti", ${ }^{71}$ Novelletes Aleksandra Glazunova pa so ga navdušile, ker da so kljub izredni barvitosti "snažne v melodični risbi [!]". Glasba Čajkovskega in Dvořaka sta mu bili najbližji. ${ }^{72}$ Po njegovo naj bi se pri Čajkovskem zrcalila "ruska duša", ${ }^{73}$ medtem ko je Dvořakova dela imenoval "krasota in prelest". Mojstrov godalni kvartet $v$ H-duru (op. 106) je dojemal kot "rožni vrt, poln najslajše glasbe". ${ }^{74}$ Cenil je tudi "intenzivno umetniško delo" Giuseppa Verdija. Rigoletto naj bi bil zrcalil "silen

65 Gl.: NA 9/1910, 2,9.

66 Gl.: NA 10/1911, 4-5, 53.

67 Gl.: NA 9/1910, 4-5, 32.

$68 \mathrm{Gl}$ : NA 9/1910, 4-5, 32.

69 Gl.: NA 11/1912, 3, 20.

70 Gl.: ibid.

71 Gl.: NA 9/1910, $1,9$.

72 Izidorju Cankarju je v pogovru povedal, da se je od slovanskih skladateljev največ ukvarjal z glasbo Dvoraka, čigar vpliva nase niti ni zmožen objektivno presoditi. Gl.: Cankar, I.: Obiski, str. 36.

73 Gl.: NA 9/1910, 4-5, 33.

74 Gl.: NA 11/1912, 1-2, 5. 
dramatični zanos [...], kajti opera je "navzlic svoji širini [...] polna umetniške vsebine in obenem skrajno koncizna." "Polet tega dela" in njegova "gonilna muzikalna" moč sta bila tolikšna, da mu je bilo ob koncu uprizoritve "kot menihu, ki je poslušal rajsko tičico; zdelo se mi je, da mi je Verdi prelepo pel en sam trenotek. ${ }^{175}$

Do nemške glasbe in nemških skladateljev je imel Lajovic hude predsodke, ki jih je težko razumeti, posebno ker svojega odpora do nemškosti ni utemeljeval z glasbenimi protiargumenti. Omenili smo že, da je Beethovnu priznal smisel za humor $\checkmark$ glasbi, ${ }^{76}$ sicer pa je zavračal uvrstitev njegovih del na naše koncertne programe pod pretvezo, da so zaradi časovne oddaljenosti nerazumljiva. Lajovčev nacionalnoobrambni razlog je verjetno botroval zapisu, naj bi bila Beethovnova dela, $v$ primeri $z$ bogastvom in svežino Dvořakove glasbe, prav dolgočasna. Ob vsaki priložnosti je poskušal dopovedati, da nemška glasba nima tiste vrednosti, kakor si ljudje nasploh o njej mislijo; tudi starejša ne, češ da ni imela nikakršne zveze s sodobnimi družbenimi in političnimi okoliščinami na Slovenskem.

Lajovčev odnos do slovenskih ustvarjalnih umetnikov je bil zelo realen, brez narodnopobudniškega prizvoka, ki bi opravičeval diletantske pomanjkljivosti. Prav premišljeno je sodil o tedanji domači reprodukciji. Zapisal je, da preživlja "suhe čase", kajti količina izvirnih skladb se mu ni zdela velika, večinoma naj bi bili "žalostno diletantski" zbori. Komaj kateri skladatelj naj bi stremel "za višjimi cilji". Očital jim je liedertafelstvo in provincialni značaj zunaj glasbenega življenja kulturnih centrov. ${ }^{77}$ Do slovenskega zamudništva je bil Lajovic strog, pogosto pa tudi nepravičen. Profesionalizacija glasbenega dela rojeva tehtnejše sadove postopoma in $\mathrm{v}$ dolgotrajnem ustvarjalnem procesu. Šibke strani Sattnerjevega Vnebovzetja je vendarle poskušal opravičiti: "Ta tehnična nezrelost in ž njo zvezana nesigurnost in neokretnost [je bila] naravnost znak tiste dobe pred N.A." ${ }^{78}$ "Tedaj se je našim skladateljsko nadarjenim ljudem zdelo že znamenito, če so se kolikor toliko naučili 'harmonije', o vsem nadaljnjem niso imeli niti slutnje; zato se jim je zdelo, da so pravila, o katerih so slišali v staromodnih 'harmonijah', meje, katere prekoračiti pri skladanju pomenja muzikalni smrtni greh; ker niso globlje prodirali $v$ glasbene umetnine raznih dob in ker so vse presojali le iz žabje perpsektive 'harmonije', niso mogli priti do spoznanja, da so vsa ona pravila le abstrakcija iz glasbenih umetnin davnih dob, da so berglje, da si ob njih pomaga učenček-začetnik do nekega razpregleda $v$ harmoniha, [...] niso [pa] prišli do spoznanja, kako nezmiselno - in za nje samo škodljivo - je, če pravila, namenjena in koristna samo s p o z n a vanju, uporabljajo kot zakon in normo pri st va rja nju. Kajti glasba [...] živi živo življenje, kot da je živo bitje $\checkmark$ naravi, in se ne briga za kratkovidno abstrahirane predpise teoretikov." ${ }^{179}$

Lajovic se je s takšnim pogledom na čitalniško preteklost postavil na čelno mesto dobronamerne glasbene kritike, ko je moral s pisanjem o glasbi prevzeti tudi vlogo pedagoga za glasbenike in vzgojitelja za občinstvo. Analitično se je poglobil v vse tiste nove skladbe, $v$ katerih je začutil avtorjevo nadarjenost, $z$ željo, da bi ga ozavestil o nujno potrebni kompozicijski tehniki. S svojim znanjem in precejšnjo skladateljsko izkušnjo je hotel usmeriti prihajajoči rod na pravo pot. Lajovčeve recenzije zrcalijo

75 Gl.: NA 11/1912, 3, 22

76 NA 9/1910, 4-5, 33.

77 Gl.: NA 9/1910, 2, 10.

78 Gl.: NA 11/1912, 4, 41

79 Gl.: ibid. 
njegov odnos do tistih sodobnikov, ki jih je najbolj zadela njegova stroga kritika. Najobširneje je pisal o večjih glasbenih oblikah: Savinovi operi Lepa Vida in Sattnerjevem oratoriju. Obema skladateljema je navkljub kritičnim opazkam prisodil izreden pomen glede na siceršnjo dediščino slovenske glasbe.

Savinove balade ${ }^{80}$ je štel za "početnice moderne glasbe na Slovenskem," kajti "prvi je zapel v harmonijah, do tedaj pri nas nepoznanih." Savin je po Lajovcu "tudi v našo operno produkcijo uvedel moderna načela muzikalne drame in moderno glasbo," njegovi dve operi (Poslednja straža in Lepa Vida) pa da sta zanj najbolj značilni in "daje[ta] njegovemu nastopu historično važnost". ${ }^{81}$

Hugolina Sattnerja je spodbujal že ob presoji njegove prve večje vokalnoinstrumentalne oblike, kantate Jeftejeva prisega. ${ }^{82}$ Predvsem je cenil Sattnerjev lirični način izražanja. Menil je, da mu je "dan dar melodične mehkobe", da pa so bila prejšnja njegova dela ujeta "v mrežo pravil", zato da "si ni upal zapeti prosto [,] tako kakor mu je bilo dano..83 $\mathrm{V}$ Jeftejevi prisegi je opazil skladateljevo "večjo okretnost in intenzivnejši izraz, ${ }^{184}$ ter hiter in lep razvoj. Ko je zvedel, da ustvarja oratorij, je zato od njega pričakoval "nekaj vrednega in lepega". ${ }^{85}$ Napisal mu je obsežno in natančno recenzijo, ki je bila v primerjavi z drugimi precej mila. Opozoril ga je sicer na nekatere okorne izpeljave, ki delu odškrnejo umetniško vrednost. Z zgledi mu je nato predlagal nekatere boljše rešitve. Sattner pa je bil preobčutljiv za kritično oceno lastnega dela. Zdelo se mu je, da njegovo delo, ki mu je ob izvedbi prineslo vsesplošno občudovanje in slavo, ne zasluži kritike, kakršno je bil zapisal Lajovic. Reagiral je polemično in v reviji sprožil ideološki spor med napredno in konservativno smerjo, ${ }^{86}$ ki ga je Lajovic zaključil leta 1912 - z molkom.

Obširneje se je Lajovic razpisal tudi o skladatelju Viktorju Parmi in njegovem Povodnem možu. Do takrat (1910) je Parma zlagal "brezskrbne" oziroma "lahkomiselne" operete. "Vnaprej omenim, da nisem med tistimi, ki Parmo malovažujejo že samo radi tega, ker se peča z opereto. ${ }^{187}$ Tu je dal jasno vedeti, da je njegov odnos do posameznih skladateljev narekovala izključno umetniška plat del in nič zunaj tega. Zato ga je bil kontrast med Ksenijo, zgodnejšo opereto (za Lajovca je bila tipični zgled sladke, neokusne, plehke glasbe) in kasnejšo kantato Povodni mož,

80 Gre za Tri Aškerčeve balade.

$81 \mathrm{Gl} .:$ NA 9/1910, 2, 9.

82 Gl.: NA 9/1910, 4-5, 31.

83 Mislil je na razne zborovske skladbe, ki jih je Sattner napisal pred kantatami. Gl.: NA 11/1912, 4, 41.

84 Gl.: ibid.

85 Gl.: ibid.

86 V 1. št. 11. letnika (1912) je urednik G. Krek napisal obširnejšo recenzijo Sattnerjevega oratorija, $v$ kateri je označil delo v celoti, medtem ko je Lajovic v svoji kritiki obravnaval bolj notranjo strukturo dela. Dve dopolnjujoči se kritiki sta bili delu namenjeni zaradi njegovega zgodovinskega pomena, saj je bil to prvi novodobni slovenski oratorij. Skladatelj pa je to razumel kot žalitev, češ, da mu dve kritiki res nista potrebni. V številki 1-2, 12. letnika (1912), je napisal obširen odgovor. Načel je ideološka vprašanja, ki pa gotovo niso bila namen ne Krekove in ne Lajovčeve kritike. Sattner je zatrjeval, da "slovensko ljudstvo ljubi zdravo melodiko, jasno harmonio, blagoglasje [...]". Sam, da je tiste vrste skladatelj, ki hoče z ljudstvom ljudsko govoriti, kar pa po njegovem mnenju ni skladateljski moto nobenega od imenovanih kritikov. Kljub vsemu je na koncu zatrdil Lajovcu, da bo poslušal njegove nasvete in oratorij popravil. Ob tej izjavi je Krek pod črto pristavil: "Čemu potem cela polemika zoper Lajovca? Težko umljivo."

Razpravljanje je zaključil G. Krek v Postludiju, kjer je na koncu opozoril na "naše popolnoma gnile razmere; razmere polne laži, zavisti in hudobnosti, polne cinizma, zahrbtnosti, neolikanosti in - umetniške neizobraženosti." Gl.: NA 11/1912, 1-2, 1; NA 11/1912, 4, 41; NA 12/1913, 1-2, 4.

87 Gl.: NA 10/1911, 4-5, 52. 
toliko bolj razveselil. ${ }^{88} \mathrm{~V}$ skladatelju je očitno odkril nadarjenost, a tudi šibko teoretično znanje.

"Pod lupo" je vzel tudi dela urednika Gojmirja Kreka, ki jih je presodil ravno tako resnicoljubno kot vse druge. Korekten urednik pa je brez opazk, ki jih je bil sicer vajen napisati pod črto, objavil Lajovčeve recenzije $v$ celoti. Lajovic je Kreka občutno bolj cenil kot pomembnega urednika; $v$ njem ni videl umetniške duše, temveč bolj "pozo umetnika". Opazko je ponovil ob recenziji Krekovega zbora Bratje, v kolo se vstopimo, in pristavil: "[...] če bi ta skladba imela toliko muzikalnega izraza in moči, kolikoršna je trdoljubnost, delavnost in zaslužnost skladateljeva za povzdigo naše domače muzikalne produkcije s pomočjo 'N.A.', potem bi bila ta skladba brezdvomno na prvem mestu $v$ naši muzikalni literaturi in neprekosljiva še za daljno vrsto let. ${ }^{189}$ Kantato Atila in ribič Josipa Michla ${ }^{90}$ je bolj na hitro odpravil: "posrečeni" kontrasti in "zmerna enovitost", medtem ko delu ni prisodil večjega pomena za slovensko glasbo. Skladbe ni podrobneje analiziral, niti ni $v$ splošnem označil skladateljevega ustvarjalnega dela.

Samo omenil je tudi Davorina Jenka in njegovo skladbo Vabilo, ki bi bila po njegovem zaslužila "večjo popularnost". ${ }^{91} \mathrm{~V}$ kritiki koncerta, na katerem je bilo izvedeno Jenkovo delo, ${ }^{92}$ je podrobneje komentiral le tiste skladbe, $v$ katerih je opazil pomanjkljivosti. Jenkova skladba se mu je zdela $v$ celoti "dobra stvar". Več besed je zato namenil že omenjeni skladbi Franca Kimovca, Izgubljeni cvet, ki se mu ni zdela tehtna. ${ }^{93}$

Dvakrat je Lajovic presojal tudi delo Stanka Premrla (Pesem žerjavov ter Zapel bi pesem žalostno). Ne samo slaba izbira besedila, motila ga je tudi šibka invencija. Skladba Zapel bi pesem žalostno se mu je zdela navkljub kratkosti dolga. Ugibal je o razlogih za to: morda je bil kriv preprost motiv, ki se prepogosto ponavlja in vselej $\mathrm{v}$ isti harmonski barvi. ${ }^{94}$

Omenjal je tudi dela Emila Adamiča, Benjamina Ipavca in Oskarja Deva. Cenil je njihovo nadarjenost, $v$ kompozicijske podrobnosti pa se pri teh skladateljih kot kritik Novih Akordov ni spuščal.

Enakovredno pozornost kot ustvarjanje je Lajovic posvečal poustvarjanju, le da je bil pri izvedbah domačih del še bolj strog in neučakan. Občutljivo je reagiral na izbiro koncertnih sporedov ter na igranje in ponavljanje domačih del. "Zahvale vredna" se mu je zdela prireditev pevskega društva Ljubljanski zvon, ki se je s koncertom spomnilo skladateljev Benjamina in Gustava Ipavca. Sočasno je Ljubljanskemu zvonu očital neizvirnost, češ da je moral poslušati že "oguljene" skladbe, namesto novih, še neznanih.

Umetnost poustvarjanja je presojal s podobnimi estetskimi merili kot ustvarjanje: "lepo" je bilo to, kar je zvenelo naravno, spontano, neprisiljeno. Poustvarjalni okus in prepričljivo čustveno podoživetje skladbe je neizpodbitno zahteval od vsakega interpreta. Slovensko pianistko Vido Prelesnik je visoko cenil. Igrala naj bi "lepo, zlasti v vseh liričnih mestih" kajti "občutje, izraz, duša, to je njeno". ${ }^{95}$ Nasprotno pa je označil

88 Gl.: 11/1912, 3, 23.

89 Gl.: NA 11/1912, 3, 20.

$90 \mathrm{Gl} .:$ NA 11/1912, 3, 20.

$91 \mathrm{Gl} .:$ NA 9/1910, 4-5, 32.

92 Gre za koncert Glasbene matice, dne 9. maja 1910, Gl.: ibid.

93 Gl.: ibid.

94 Gl.: NA 11/1912, 5-6, 47.

$95 \mathrm{Gl} .:$ NA 9/1910, 1, 2. 
takrat še mlado in neizkušeno pevko Pavlo Bole, češ da je svoj part v Parmovem Povodnem možu pela sicer zadovoljivo, vendar brez občutka. Lajovic je ugibal, če je bila morda preveč odvisna od šole. Resnici na ljubo se je spotaknil tudi ob pevko Jeanette Foedransperg. ${ }^{96} \mathrm{Da}$ je pevka pela mrzlo, "ker menda [...] samo na to misli, kako prinese posamezni ton pravilno, in tako samo posamezne tone producira [,] mesto sklenjeno celoto melodije. ${ }^{197} \mathrm{~V}$ kritičnem poročilu operne sezone jo je ponovno omenil. Tokrat je iskal vzrok za "psihološke zavore, [ki] držijo njeno pevsko in igralsko gesto v strogih sponah." Krivdo za njen slab glasbeni razvoj je naprtil ljubljanski šoli.

Josipa Križaja je večkrat ovekovečil kot pevca, ki da je "obdarjen z lepim glasom," ${ }^{98}$ in $v$ skladu $z$ Lajovčevo izvedbeno predstavo: "živo in samostojno občuteno". ${ }^{99}$ Tudi "svež, ljubek glas in [...] priprosto[,] iskreno prednašanje" Pavle Lovšetove je bilo to, kar je pričakoval od solističnih izvjalcev.

Kritično je poročal tudi o koncertu češkega tenorista Karla Burriana; ta naj bi "očitno pokazal da je njegova prava moč le v dramatičnem izrazu", medtem ko je lirične arije odpel "akademično mrzlo". ${ }^{100}$ Od izvajalcev je zahteval korektno izvedbo glede na slog in izraz skladbe ter pevsko tehnično perfektnost. Ob tem se ni oziral niti na predvideno niti dejansko užaljenost. Petje tenorista Leopolda Kovača je označil kot diletantsko; s tem naj bi pevec ne škodoval le samemu sebi, ampak je s svojim nastopom razžalil tudi skladatelja. ${ }^{101}$

Interpretacija, ki se ni menila za enovitost glasbenega dela, je sodila med najslabše vrste. Trganje celote se je po njegovem mnenju "epidemično" razširjalo predvsem pri pevskih zborih. Krivdo je naprtil zboru Glasbene matice, ker so se domala vsi drugi zgledovali po njem. Mislil je na neustrezno, predvsem prepogosto dihanje, tako da so $v$ skladbah nastajale nepotrebne pavze, ki seveda niso bile napisane. To nepravilnost pa je kar ironično opisal: "To ni nikako petje, ampak čisto navadna rezanica. Ta bolezen izhaja iz [prakse] Gl. Matice, kjer se izvršuje ta kruta vivisekcija melodij in besednih stavkov leto za letom hujše, tako da se publiki, mesto da bi dobila pred oči vitko, zdravo raščeno melodijo, godi kot tistemu, ki je šel strahu iskat: najprej pade predenj noga, nato roka, potem glava, itd. ud za udom. Tako se brezobzirno seka, ne glede na cezure melodičnih ali besednih stavkov, ne glede na to, ali je na zadevnih mestih sploh najmanjši oddih dopusten, da, celo na takih mestih, kjer je, recimo, ločitev dveh besed očividno nedopustna.. ${ }^{102}$ Takšno interpretacijo je Lajovic pripisal tudi Ljubljanskemu zvonu. Kriv naj bi bil Zorko Prelovec, dirigent tega zbora; v eni od kritik ga je Lajovic označil kar za "brezsrčnega rablja". ${ }^{103} \mathrm{Na}$ to žalitev je Prelovec reagiral v časopisu Učiteljski tovariš. ${ }^{104}$ Trdoživo je sprejel strogo sodbo, češ, da naj "bogovi z Olimpa", le pokažejo na napake, zahteval pa je odgovor na vprašanje: Kje naj pevci dihajo?" ${ }^{105} \mathrm{~V}$ naslednji Lajovčevi kritiki njihovega koncerta $(\mathrm{v}$ zadnji številki istega letnika Novih Akordov) mu je Lajovic odgovoril z mislijo, da bi

$96 \mathrm{Na}$ tako imenovanem "Večeru bratov Ipavcev 'Ljubljanskega zvona' je izvajala samospeva Benjamina Ipavca, Ciganka Marija in Čez noč, čez noč ter romanco Ljubislave iz Tičnika. Gl.: NA 11/1912, 1-2, 6. 97 Gl.: ibid.

98 Gl.: NA 11/1912, 3, 23.

99 Gl.: NA 11/1912, 4, 43

$100 \mathrm{Gl}$.: NA 11/1912, 1-2, 5.

$101 \mathrm{Gl}$ : ibid.

102 Gl.: NA 11/1912, 1-2, 6.

$103 \mathrm{Gl}$.: ibid.

104 Gl.: Učiteljski tovariš 52/1912, 28, 3.

$105 \mathrm{Gl}$.: ibid. 
morali glasbeno nadarjeni ljudje to sami čutiti. ${ }^{106}$ Drugo slabost številnih zborov je Lajovic videl $v$ tem, da so rasli kot gobe po dežju in celo zavirali razvoj instrumentalne glasbe. Na to nevarnost je Lajovic že poprej opozarjal. Najprej v Novi dobi leta 1905, zato $v$ Novih Akordih ni več varčeval z besedami, niti jih ni izbiral. "Ti pevski zbori! Očividna coklja postajajo živahnejšemu koncertnemu življenju. Zdi se, kakor da vlada $\checkmark$ Ljubljani prepričanje, da brez pevskega zbora ni mogoče napraviti koncertnega programa," nato pa se je vprašal: "Čemu pa imamo sicer po številu majhen po svoji zmožnosti pa jako dober in poraben orkester Slovenske Filharmonije? Ali naj bo samo za gledališko in gostilniško muziko, sicer pa naj počiva?" ${ }^{107}$ Ponovno je opozoril, da je za razvoj glasbene kulture nekega naroda prav tako (morda še bolj) pomembna instrumentalna glasba kakor vokalna. Težišče koncertnega dogajanja na Slovenskem bi naj postopoma prevzel orkester, zbor pa naj bi mu stal ob strani. To bi po Lajovcu morala upoštevati tudi Glasbena matica, ki ni spodbujala instrumentalistov; še vendo je popularizirala masovnost svojega zbora. Lajovic se je postavil kot kašen neupoštevani učitelj $z$ besedami: "Zbor mora biti zraven, pa naj gre za male ali velike stvari. Pa kakšen zbor! Wer zählt die Völker!? Še par let, in zbora bo toliko, da za publiko ne bo $v$ nobeni dvorani več prostora, $v$ dvorani bo samo oder, na njem pa osemdeset tisoč sopranov in altov in 70 tisoč moškega zbora, zapeli pa bodo same take pesmice, katerih ne bo nobena čez 8 taktov dolga. Zakaj pri nas ne velja pravilo, da naj bodo sredstva za izvajanje primerna vsebini in dimenzijam proizvajane umetnine? Ravno narobe, čim manjša stvar, tem večji zbor." ${ }^{108}$ Številčno večanje zborov se je po njegovem mnenju prenašalo tudi na druga pevska društva. Lajovic je izvzel le klerikalno društvo Ljubljana, ki da je $v$ tistem času hotelo strankarsko konkurirati Matičinemu zboru. Prevzemanje napak se mu je zdelo nezaslišano: "Vraga, ali smo res tako kosmatih ušes, da jih je potrebno posebej briti, predno naj opazimo to vriščečo nerazmernost?" 109 Večkrat je poudarjal, da morajo biti "uporabljena sredstva primerna vsebini umetnine," zato se mu je ponavljanje istih zahtev, ki naj bi bile sicer same po sebi umevne, zdelo povsem odveč. Več ko je bilo neizobraženih pevcev, bolj okoren in neroden je bil zborovski ansambel. Nazadovanje Matičinega zbora je Lajovic takole komentiral: "To stagniranje molče trobenta po reformah"; 110 "Radikalno zmanjšati zbore in jih kvalitetno zboljšati."111 Menil je, da bo "z majhnim, a dobrim koncertnim zborom [...] mogoče živahnejše koncertno delovanje in pomnožitev koncertnih proizvajanj, ki je nujno potrebna", saj "pri dosedanjem okornem načinu koncertnega delovanja s 150-glavim zborom, že danes prerokujem, da do sodnega dne ne bo naša publika sproti slišala niti tega, kar bo najboljšega sproti rodila naša skromna muzikalna literaturica. Iz kake druge literature pa še celo ne bo nikdar slišala ničesar. ${ }^{112}$

Vedno kadar je imel priložnost pa je spodbujal rast orkestra Slovenske filharmonije. Eno samo kritično poročilo se nanaša na koncert, kjer je imel orkester "glavno besedo", ${ }^{113}$ kajti največkrat je nastopal "v družbi" z zborom Glasbene matice.

106 Gl.: NA 11(1912), 5-6, 47.

107 Gl.: NA 11/1912, 1-2, 5.

$108 \mathrm{Gl}$ : ibid.

$109 \mathrm{Gl}$ : : ibid.

$110 \mathrm{Gl}$.: ibid.

111 Gl.: ibid.

112 Gl.: ibid.

113 Gl.: NA 11/1912, 3, 21. 
Ob izvedbi Lajovčevega Adagia za orkester je posmehljivo zapisal, da so zaradi "preširokega tempa" iz njega naredili "pravo vlečeno potico, na kateri občinstvo po pravici ni imelo okusa." 114

Večkrat se je iz tega orkestra izkristaliziral manjši sestav, ki je prirejal komorne koncerte. To so bili tisti dogodki, ki jih je Lajovic najrajši kritično spremljal. Nasproti izvedbam velikih amaterskih zborov so bili komorni koncerti zanj priložnost, ko sta se mogli umetnost in poustvarjanje zliti $v$ izenačeno glasbeno - estetsko doživetje. Tega si je Lajovic sicer želel tudi od drugih ansamblov, vendar je natančno vedel, da si ob takratni ravni slovenske instrumentalne glasbe še ni smel obetati izjemnih interpretacij.

Češki dirigent Václav Tálich, dirigent Slovenske filharmonije, je bil pri Lajovcu kar najbolje zapisan. Sredi Ljubljane je zares učinkoval kot čudežna reproduktivna osebnost. Toda ljubljanske strankarske in glasbeniške intrige so $v$ najkrajšem času dosegle, da takrat še mladi mojster taktirke ni videl svoje umetniške perspektive $v$ Ljubljani. Lajovca je ta novica dobesedno osupnila, zato je pri priči napisal kritično opazko za rubriko Pêle-Mêle. Obregnil se je ob reklamo za koncert Glasbene matice (14. Jan. 1912), češ, da je bil Václav Tálich, "potisnjen v kot" na koncertnem listu in na plakatih. Ob tem se je vprašal, če se je to zgodilo po naključju ali namerno; odgovoril si je kar sam; "Jaz, ki sem, žal, močno pesimistične nature, slutim namen [...] in žal mi je, da se pri tako resnem institutu uporabljajo tako malenkostna in tako nizkotna sredstva!" ${ }^{115}$ Leta 1912 je Václav Tálich zapustil Ljubljano, Lajovic pa je utemeljeno presodil, da je "ž njim [...] odšel brezdvomno največji reproduktivni talent," kar jih je do takrat premoglo domače glasbeno poustvarjanje. Po Lajovčevemu mnenju bi bil on "edini, ki bi mogel, začenjajoč tam, kjer je nehala Hubadova delovna roka, voditi dalje koncertno delo GI.M. v starem blesku in nezmanjšani slavi do vedno višjih ciljev. ${ }^{1116}$ Pri tem se je spotaknil ob lahkomiselnost slovenskih glasbenikov, češ da ga nihče ni niti poskušal obdržati. "Tálich je odhajal od nas skoro neopažen! In nevesel mi je pogled v našo muzikalno bodočnost!", je zaključil svoje poročilo o zadnjem koncertu Slovenske filharmonije pod Tálichom. ${ }^{117}$

Tálicha je zamenjal bivši kapelnik vojaške orkestra c. in kr. pešpolka št. 97 v Trstu, Peter Teply. Lajovic ga je označil "kot dobrodošlega kulturnega delavca". ${ }^{118}$ Še bolj vesel pa je bil slovenskega dirigenta Nika Štritofa, ki je namesto Tálicha prevzel vodstvo operete. "Vivat sequens!", je vzkliknil in izrazil opombe o izobraževalni dejavnosti Glasbene matice: "S tem bi bil storjen začetek, da dobimo počasi nekaj svojih dirigentov, za kar se dosedaj celo niti od strani Glasb. Matice, ki bi bila v prvi vrsti $v$ to poklicana, tekom lepe vrste let, kar živimo živahneje kulturno življenje, ni storil niti najmanjši poskus." ${ }^{119} \mathrm{~S}$ tem se je Lajovic dotaknil še glasbenega šolstva, ki ga sicer ni pogosto omenjal.

Lajovčevo pero je bilo ostro, sodbe stroge in nepopustljive, zabeljene s pikrimi puščicami. Način njegovega pisanja je tako svojevrsten, da bi bili njegovi prispevki

114 Gl.: NA 11/1912, 1-2, 5.

115 Gl.: NA 11/1912, 3, 32.

116 Gl.: NA 11/1912, 3, 21. Matej Hubad je že leta 1909 želel prepustiti vodstvo Matičinega zbora Václavu Tálichu. Odbor Glasbene matice je predlog odobril, nastala pa so ideološka razprtja med pevci, ki novega dirigenta niso sprejeli. Tálich je zato takoj odstopil. Zbor Glasbene matice so od takrat naprej pogosto spremljale krize. Prim.: Mahkota, K.: Kronika PZGM, 2. Knjiga, str. 161.

117 Gl.: NA 11/1912, 3, 21.

118 Gl.: ibid.

119 Gl.: NA 11/1912, 3, 25. 
prepoznavni tudi brez podpisa. Izražal se je sicer jasno, vendar si je pogosto za strokovne izraze sposojal besednjak iz vsakdanjega življenja in uporabljal tujke, zlasti srbizme in hrvatizme, ki jih je razumeti kot odziv panslavistične ideje. Posamezne glasbene pojme je rad popredmetil ali celo poosebil. Glasbo je umeval kot živo bitje. Večkrat se zdi, da se je zatopil $v$ pisanju kritik v globino lastnega kompozicijskega premišljevanja in pozabil, da piše kritiko za javnost. Včasih je sredi prispevka začel pisati neposredno tistemu, ki mu je bila kritika namenjena, kakor da bi šlo za dialog ("preveč nemirni ste," je pisal Ristu Savinu ${ }^{120}$ ), nato pa nadaljeval spet v tretji osebi, kakor je bil začel.

Njegovo pisanje se je pogosto približalo ravni pogovornega izražanja, kljub temu ni bila strokovnost kritičnega poročanja nikoli oškodovana. Imel je razmeroma bogat besedni zaklad (pomnožen $s$ tujkami), zato ni "žongliral $s$ praznimi besedami in žvenkljal z brezvsebinskimi izrazi". ${ }^{121} \mathrm{~S}$ tem je zgledno uresničeval svojo zahtevo o načinu pisanja glasbenih kritik in vztrajal - vse dotlej, ko so se strankarska nasprotja že hudo vgnezdila $v$ glasbeniške vrste. Sodu je izbila dno Sattnerjeva reakcija na omenjeno kritiko Vnebovzetja. Anton Lajovic se po letu 1912 ni več oglasil v Novih Akordih.

Analitični prerez posameznih kritičnih prispevkov v Novih Akordih navaja k sklepu, da moremo in smemo to njegovo dediščino, skupaj $s$ preostalimi publicističnimi prispevki, ki jih je objavil pred prvo svetovno vojno, pojmovati za enega od temeljev slovenske glasbene kritike. Bil je izobražena osebnost $s$ širokim obzorjem in človek $s$ pokončno držo, ki ga glasbeniške intrige in lažen odnos do umetnosti niso zanimale. Močan nacionalni ponos veje iz domala vseh njegovih kritik. Slovenske manjurednostne občutke je spodbujal kot oster razumnik, ki se je zavedal napak in prednosti v samobitnem nacionalnem glasbenem prizadevanju.

Osnovna ideja Lajovčevega kritičnega dela je bila nadgradnja čitalniškega izročila z modernejšimi glasbenimi nazori, ki bi morali sloneti na splošni preobrazbi mišljenja o glasbi. Problemov se je loteval resno, odločno, celo z neko apriornostjo, ki skorajda ni dopuščala ugovorov. Predstavo o stanju slovenske glasbe in njenih perspektiv je premišljeno gradil z lastnimi kritičnimi merili. Vztrajno jih je prilagajal glede na trenutni predmet kritike in $s$ tem pomembno vplival na počasne in značilne premike $v$ slovenski glasbi.

$\mathrm{V}$ pogovoru z Izidorjem Cankarjem je kasneje (v dvajsetih letih) nazorno orisal svoje mnenje o slovenski glasbi, ko se je vrnil z Dunaja: "Pomisliti je treba, da je bila do tega časa naša muzikalna produkcija na jako primitivni stopnji. [...] Temu stanju produkcije je bilo primerno tudi to, kako je naša kritika in publika vrednotila našo produkcijo. To vrednotenje je bilo brez vsakih višjih vidikov. [...] Pri nas so se producirali samo zbori, niti solospeva ni bilo nobenega takega, ki bi ga mogli resno jemati." ${ }^{122}$

Lajovic je zagovarjal poklicno usposobljenost glasbenikov: ustvarjalcev, poustvarjalcev in kritikov. Videl je, da diletantizem v najboljšem pomenu besede nikakor ni kos sodobnim zahtevam. Nobene od napak in površnosti ni spregledal $v$ delu slovenskih skladateljev. Od njih je zahteval za tisti čas moderno skladateljsko naziranje, neoporečno čist in tehten kompozicijski stavek ter estetski čut. Spodbujal je ustvarjanje

120 Gl.: NA 9/1910, 2,9.

121 GI.: NA 9/1910, 4-5, 31.

122 Gl.: Cankar, I.: Obiski, str. 34. 
deficitarnih zvrsti, predvsem instrumentalno glasbo vseh žanrov (od solistične komorne do večjih zasedb in cikličnih vokalno-instrumentalnih oblik).

Še bolj zahteven je bil do reproduktivnih ustvarjalcev. Natančno interpretacijo (takšno, ki ostaja zvesta notnemu zapisu in skladateljevi zamisli) je štel za odlično spodbudo ustvarjalcem, višjo umetniško prodornost interpretov pa za splošni temelj koncertnega življenja, kakršnega imajo pomembna tuja glasbena središča.

Lajovčev kritiški koncept se je dotikal tudi območja glasbene sociologije, kajti glasbena umetnost naj bi živela $v$ trojni človeški navezavi ustvarjalec - poustvarjalec občinstvo in je neposredno odvisna od njihovih medsebojnih razmerij. Pravilnemu razumevanju (podoživetju) izvedene skladbe je zato posvetil precej pozornosti. Vemo, da je bil vsakršen premik od prejšnje slovenske prakse težaško delo. Občinstvo je bilo še vedno pod vtisom čitalniškega (ljubiteljskega) muziciranja ter navad in razvad, ki niso imele veliko skupnega $z$ glasbo kot umetnostjo. Naklonjeno je bilo predvsem nezahtevni vokalni oziroma vokalno-instrumentalni glasbi, to pomeni na boljše in slabše uglasbitve besedila, medtem ko je bila percepcija avtonomne instrumentalne glasbe še trd in neprivlačen oreh. Od tistih glasbenih piscev, ki so pisali za širše občinstvo, je zahteval, naj s preprostimi, a prepričljivimi razlagami izobražujejo občinstvo. Vedel je, da morajo potekati spremembe $v$ glasbenem življenju sinhrono: noben člen iz verige ustvarjalci-pousvarjalci-poslušalci ne bi smel v kritikah zastajati.

Skladatelj bi moral svojo notranjost prestavljati $v$ tonski jezik, glasba bi potemtakem postala izraz umetnikove duše. Lajovic je nenehno uporabljal pojem "gorko občutene" melodike; razumemo ga kot odraz lastne lirične naravnanosti, osnovane na naravni lepoti, ne pa kot kontrast razuma $v$ glasbi. O razumu $v$ glasbi ni govoril, štel ga je kot samoumevno intelektualno lastnost ustvarjalca.

Povsem razumljivo je, da se je Lajovic zavzemal za razvoj slovenske glasbe in da ni s simpatijo gledal na delovanje (in sočasne uspehe) nemške Filharmonične družbe. Mnogo težje je razumeti dejstvo, da je človek $s$ takšno izobrazbo, temeljitim umevanjem umetnosti in njenega bistva, a priorno nasprotoval nemški umetnosti. Lajovica je obhajala svojevrstna ideja o identifikaciji slovenske glasbe, ki naj bi ne spominjala na nobeno drugo. Samobitna glasbena kultura se je na Slovenskem spočela razmeroma pozno, nujno potrebne vzore (kompozicijske in poustvarjalne) naj bi po Lajovčevi predstavi oziroma utopiji iskala $v$ samosvojih različicah slovanske prabiti. Temu v prid govorijo njegovi največkrat uporabljeni izrazi: "mehka linija", "gorko čustvo", "milina izraza", "strastna gorkota".

Svojih zahtev se je dosledno držal in jih poudarjal ob vsaki priložnosti. Pri tem je bil večkrat neusmiljen in navidezno nerazumevajoč do glasbenih kolegov. Pogosto ga je vleklo $v$ posmehljivo žaljiv način izražanja, ne glede na to, komu je bila kritika namenjena. Ni skoparil s trdimi, grobimi ugotovitvami o skladbah, izvajalcih ali (nespametni) glasbeni politiki. Z današnjega vidika je nekatere od glasbenikov tudi krivično in nepremišljeno odpravil (npr. Zorka Prelovca).

Lajovčevi sodobniki kritikam in sodbam niso ugovarjali; bodi si niso upali sprožiti še hujše reakcije, bodi se jim ni zdelo vredno. Edini ugovor je bil Sattnerjev, ko je označil Lajovčeve in Krekove umetniške nazore za "ultramoderne". Lajovčeva drža je bila preveč pokončna, da bi na ta "napad" sploh odgovoril. Raje je umolknil in (leta 1912) prekinil sodelovanje z Novimi Akordi. Glede na to, da je dve leti kasneje pisal o kulturni politiki v Slovanu in se tam obregnil ob Nove Akorde, bi lahko pomislili, da je morda prišel v spor z Gojmirjem Krekom in zato prenehal sodelovati z glasbeno revijo, kajti zanj polemika s Sattnerjem ni bila zadosten razlog za umik tako močne osebnosti, 
kot je bil Lajovic. $V$ tem trenutku namreč ne poznamo gradiva, ki bi utegnilo pojasniti vprašanje.

Kljub temu smemo reči, da je bil Anton Lajovic rojen kritik. Njegovo kritično delo $v$ Novih Akordih je bilo svojevrstno in pomembno $v$ več smereh. Pripomogel je $\mathrm{k}$ temu, da se je slednjič premaknilo pisanje o glasbi $v$ bistvena vprašanja o tej veji umetnosti. Najbolj je vplival na mlajši rod slovenskih ustvarjalcev. Takšen je bil prav gotovo Emil Adamič. Lajovic se mu je iz obdobja Novih Akordov takole zapisal v spomin: "Hodil je svoja pota, samotna, od neumnežev zaničevan, od zavidljivcev zasmehovan, od prijateljev občudovan. ${ }^{123}$

\section{SUMMARY}

Anton Lajovic ranks among those Slovene musical artists who at the turn of the century - when in musical art, in the broader world and in this country, new trends were comping up - felt genuinely responsible for the music of their time and of the time ahead. The present contribution gives a detailed account of his role as a regular critics for the magazine "Novi akordi" in the years 1910-1912 (from the ninth to the eleventh annual volume). The publications are namely most characterisic of his publicising and critical work from the beginnings (1907) until World War I, which period is taken to be the concluded developmental phase in the life of this extraordinary creative and thinking man in the field of music. In fair and well-argued musical reviews, in articulate views and ideas he envisaged the precondition for boosting Slovene musical work (training of professional musicians and of public for achieving a higher level). He felt himself capable - through his demeanour as a personality and his knowledge of music - of impressing fresh guide-lines on the musical developments on his native soil. The basic idea of his work as reviewer was to build upon the reading-room tradition further on through more modern musical views and through an overall transformation of the thinking about music. He was tackling the problems seriously, resolutely, even with a kind of a-priori approach admitting of almost no objections. With a clear idea of the situation in Slovene music and of its perspectives he was in a well-considered way shaping the reviewing standards. He was persistent in expressing them and in stressing them on every occasion: in this way he exterted a significant influence on slow, yet characteristical shifts in Slovene music. His pen was sharp, his judgements rigorous and relentless, often spiced with pungent shafts. Tirelessly he persisted all along until the then current party antagonisms had become already strongly infilterated in the ranks of musicians. A. Lajovic's critical contribution to "Novi akordi" contributed towards purification and fresh winds in the conception of musical art - at least with that generation of younger musicians who were known already to him himself as "thinking seriously". An analytic cross-section of his appraisals sheds light on Lajovic's ideas and views in music and these are in the present contribution dealt with in considerable detail.

123 Gl.: Adamič, E.: Deset let "Novih Akordov", Ljubljanski zvon 33/1913, 240. 